\title{
TOXICITY AND SYMPTOMATIC IDENTIFICATION OF SPECIES INVOLVED IN SNAKEBITES IN THE INDIAN SUBCONTINENT
}

\author{
KUMAR V. (1), MAHESHWARI R. (1), VERMA H. K. (1)
}

(1) Department of Electrical Engineering, Indian Institute of Technology, Roorkee, India.

ABSTRACT: Snakebites, being the major occupational hazard for farm workers, claim a large number of lives in the Indian subcontinent. During the course of medical management, identification of the biting species is given a low priority, resorting to prescription of polyvalent anti-snake venom. Whereas the World Health Organization (WHO) recommends monospecific anti-snake venom instead of polyvalent anti-snake venom. Thus, it is essential to identify the aggressor species either by a visual inspection or by the symptoms of the victim. Along with the four deadly venomous species (cobra, krait, Russell's viper, and saw-scaled viper), there are a number of other species of medical importance, whose venoms and bites have not been paid much attention. Thus, a misclassification resulting into erroneous treatment cannot be ruled out. This paper discusses the nature, constitution, and toxicity of venoms and their possible toxic effects on victims of snakebites. An attempt has also been made to categorize the distinctive symptoms due to the bites of the four major venomous species and their severity grading.

KEY WORDS: aglyphs, envenomation, opistoglyphs, proteroglyphs, snakebite, species-specific toxicity.

\section{CORRESPONDENCE TO:}

VINOD KUMAR. Department of Electrical Engineering, Indian Institute of Technology, 247 667, Roorkee, UA, INDIA. Phone: 911332 274172. Fax: 911332273560.

Email: vinodfee@iitr.ernet.in 


\section{INTRODUCTION}

Snakebite is an occupational hazard for farmers and farm laborers in the Indian subcontinent. Every year approximately 15,000 people reportedly die due to snake venom interaction in India alone (1). However, unreported deaths are estimated to be many times greater than the reported cases in the subcontinent. Astonishingly, very little mention has been made in the medical curricula, which may be one of the contributing factors to the high number of fatalities $(24,33)$. Statistics show that the majority of victims belong to the group of rural farmers in the productive age, so any loss of life in snakebite may severely affect the economy of the victim's family (30, 31).

The Indian subcontinent, being tropical, harbors a variety of venomous and nonvenomous snakes (18). The four major venomous biting species are cobra or Naja naja (Linné, 1758), krait or Bungarus caeruleus (Schneider, 1801), Russell's viper or Vipera russelli (Shaw, 1797), and saw-scaled viper or Echis carinatus (Schneider, 1801). The former two belong to the Elapidae and the latter two belong to the Viperidae family. Although the environment, habitat and human activities determine the number of incidences due to various species, Echis carinatus claims the majority of bites in most parts of the subcontinent (7).

Often, during the course of medical management, identification of the species is not paid much attention and the current practice is to prescribe equine polyvalent antisnake venom serum (ASV) to be administered intravenously, which neutralizes all the four types of snake venom $(3,41)$. However, the ideal treatment is with monospecific/monovalent antivenom, since this involves administration of a lower dose of antivenom protein compared to polyspecific/polyvalent antivenoms $(2,16)$. The current practice of polyvalent ASV application is also under scrutiny with the assorted methods of administration suggested $(7,5,36)$.

Another substantial issue in this regard is that a snakebite victim may exhibit certain signs and symptoms, even if the species does not belong to the four types mentioned above. This may lead to misclassification as well as improper treatment. Therefore, it is important to understand all the species whose bite, venom or secretion may be clinically significant. It is equally pertinent to know the toxic ingredients and specific symptoms likely to develop in the victim for the identification of the species in every case. 


\section{SNAKE SPECIES OF MEDICAL IMPORTANCE}

The snake species of interest can be classified into three main categories based on their venom delivery apparatus. Proteroglyphs form the most venomous group while the opistoglyphs are mildly toxic. Aglyphs are non-venomous, but they are also medically important since they are capable of causing injuries.

\section{Proteroglyphs}

Snakes with front fangs belong to this category. All the four venomous snakes previously mentioned, and three more venomous but euphemistic proteroglyph snakes are commonly encountered in the Indian subcontinent.

a. Cobra: The subcontinent harbors many varieties of cobras but the primarily identified species are binocled or spectacled cobra, monocled cobra, black cobra, and albino cobra (44). No marked variation in their venom has been observed by any research group, hence no separate descriptions of different varieties are provided here.

b. Kraits: In the subcontinent, there is a variety of kraits which vary in size, color and toxicity, but the common krait is considered the most aggressive species. It is reportedly responsible for the biggest number of snakebite deaths in Sri Lanka (19). It has small fangs and therefore indistinct bite marks.

c. Russell's Viper: It is a large and thick viper with one chain of rings on the vertebrae and two more dorsal chains symmetrically placed on either side. It has aggressive tendencies and may bite under provocations (18).

d. Saw-Scaled Viper: It accounts for more than two-third of the venomous bites in the region (14). This small snake camouflages in the background, therefore the victim often fails to sight it, particularly in the dark. It is aggressive and coils in the shape of " 8 " with a sound of a saw cutting wood by rubbing its scale.

e. Bamboo Pit Viper (Trimeresurus gramineus, Shaw, 1802): It is a greencolored, yellow-bellied snake, which often camouflages in the leaves and therefore causes frequent envenomation to the forest dwellers. As a part of the restructured pit viper phylogeny, some publications mention it as a lineage of Trimeresurus stejnegeri $(11,26,43)$. 
f. King Cobra (Ophiophagus Hannah, Cantor, 1836): The largest venomous snake found in the Indian subcontinent, it has some aggressive tendencies. However, no significant fatalities due to this species are reported in the subcontinent nowadays.

g. Common Sea Snake (Enhydrina Schistosa, Daudin, 1803): It is the most commonly encountered estuarine species. This snake is one of the most venomous and is found in the coastal aquaculture and river deltas. However, it is not aggressive towards human beings and its bites are very rare.

\section{Opistoglyphs}

The advanced snakes or the Colubridae (Opell, 1811) have large posterior teeth, which may or may not be grooved. Evolution of toxins in the advanced snakes (Colubridae) predated the evolution of advanced, front-fanged delivery mechanisms (13). From a large spectrum of Colubridae of the subcontinent, the most frequently encountered species are discussed here.

a. Common Cat Snake (Boiga trigonata, Schneider, 1802): This snake has large eyes and large head, and resembles a saw-scaled viper except for the simple " $Y$ " design on its forehead compared to the fighter plane shape seen on a viper forehead. The posterior fang marks may be absent in the bite but erythema, purpura or edema may develop locally (43).

b. Green Vine Snake (Ahaetulla nasutus, Lacepede, 1789): This beautiful snake resides in dense forests. Its head has a leaf-like appearance, helping to camouflage in the green background. The large oval shaped eyes are the prominent feature. Its venom is mildly hemotoxic, thus the victim may feel dizziness for a couple of days with low-grade fever coupled with local edema or erythema at the bite site.

c. Common Wolf Snake (Lycodon aulicus, Linné, 1754): This snake resembles a krait but is lighter in color. Also, the transverse bands are wider than the paired narrow transverse bands of a common krait. It has two sharp and long maxillary teeth, which may be confused with fangs. Dizziness and slight bleeding from the bite site may follow.

d. Banded Kukri Snake (Oligodon arnensis, Shaw, 1802): This light-colored snake has transverse dark bands on the entire body with a "V"-shape mark on 
the forehead. The maxillary teeth are bent inside, and an accidental bite may look like an abrasion without significant symptoms.

e. Common Rat Snake (Ptyas mucosus, Linné, 1758): It is a large-sized snake commonly found in the human habitat. Although it avoids encounter with human beings, it becomes aggressive in the mating season. Venom interaction is rare due to the posterior fangs, but because of its large mouth and teeth, mechanical injury and anxiety-related symptoms may be observed in the victim.

f. Common Pond Snake (Natrix piscator, Schneider, 1799): This dark-colored snake may raise its head and may imitate a cobra. Seen in different checkered patterns, it often bites near water or in the water when someone steps on it accidentally. Its venom is potent enough to kill a fish or a frog, but may cause only local symptoms to a human being, mainly due to the mechanical injury.

\section{Aglyphs}

These non-venomous snakes are commonly encountered in the subcontinent. A number of aglyph snakes may not be aggressive even if approached too close. However, the two aggressive aglyphs are discussed here.

a. Common Indian Rock Python (Python molurus, Linné, 1758): This intimidating large snake is often seen on trees and in large crevices. A well-developed python may attack a human being if reached too near. It may squeeze around the prey to cause transverse bones fracture and asphyxia to kill and swallow subsequently.

b. Common Sand Boa (Eryx conicus, Schneider, 1801): This snake resembles Russell's viper in shape, size and color, with a difference that it has one series of irregular dorsal patterns on the vertebra whereas the latter bears three chains. Its head is smaller; the neck is not distinguishable and the tail is conical. The tail helps in digging and the species remains hidden in the sand. An accidental step on a member of the species may result in many bites and a consequent mechanical injury. 


\section{TOXICITY AND CLINICAL FEATURES OF BITES}

Snake venoms contain species-specific proteins with widely varying toxicological features as summarised bellow.

\section{Proteroglyphs}

a. Cobra: The venom consists of three types of proteins: cardiotoxin, neurotoxin, and phospholipase A2 (PLA $)$. Toxins belonging to cardiotoxin and neurotoxin groups are small molecular weight proteins, cross-linked by four disulfide bridges at homologous positions. Members of these two toxin groups share more than $50 \%$ homology in their amino acid sequences but exhibit drastically divergent biological properties (42). It would be appropriate to mention here that snakes possibly adhere to a policy of structural economy by utilizing a limited number of molecular molds to achieve a remarkable functional diversity (32).

In contrast to cobra neurotoxins, which interact with the post-synaptic acetylcholine receptor, the cardiotoxins show no defined cellular targets and have very diverse pharmacological effects, including lethal toxicity, hemolysis, muscle contracture, and activation of tissue phospholipase C (46). Cardiotoxins also involve membrane depolarization and ultimate cytolysis in many types of tissues; so it is referred to as direct lytic factor (17). They also exhibit activities like prevention of platelet aggregation and inhibition of $\mathrm{Na}^{+}$, $\mathrm{K}^{+} \mathrm{ATPase}$ and protein kinase $\mathrm{C}(21)$. Other studies suggest that cardiotoxininduced $\mathrm{Ca}^{2+}$ influx may cause cell injury resulting in ischemia and thus causing the release of a large amount of catecholamines $(8,50)$.

Phospholipase $A_{2}$ catalyses the hydrolysis of phospholipids and generates free fatty acids and lyso-phospholipids. Severe inflammation and necrosis in the affected tissue area may be due to the cardiotoxins and/or $\mathrm{PLA}_{2}$ or their synergistic effect (47). Later, it was identified that increasing doses of $\mathrm{PLA}_{2}$ do not constitute a change in the serum level of the pro-inflammatory cytokines tumour necrosis factor (TNF)- $\alpha$ and interleukin (IL)-1 $\alpha$ but induce a dosedependent increase in the anti-inflammatory cytokine IL-1ra (10).

Selective interaction of cardiotoxins and $\mathrm{PLA}_{2}$ with glycosaminoglycans may be responsible for cardiotoxicity and local symptoms like inflammation and 
necrosis near the affected tissue area (47). Cobra can deliver $60 \mathrm{mg}$ of venom in a single bite, which is five times its fatal dose (16).

b. Kraits: Out of the two varieties of Bungarus species found in the subcontinent, common krait (Bungarus caeruleus) and banded krait (Bungarus fasciatus), the former is responsible for nocturnal human bites and large mortality (19, 40). The latter is not so aggressive and envenomation by this snake in the subcontinent has not been reported in literature.

The common krait has small and fixed front fangs. Its bite may not be painful and the local symptoms are barely discernible, but systemic symptoms and abdominal pain are the distinctive features of a krait envenomation, along with hypokalemia $(19,37)$. The neurotoxins in the krait venom are prominently presynaptic and prevent release of acetylcholine at the neuromuscular junctions (1). Krait venom has a fatal dose of $6 \mathrm{mg}$ with an average deliverable dose of $20 \mathrm{mg}(16)$.

A brave victim has published his own experience, mentioning the local and systemic manifestations, but it appears to be a case of misclassification of the species (20). An attempt has been made to develop an ISFET (ion sensitive field effect transistor)-based immunosensor for the detection of $\beta$ Bungarotoxin, a major constituent of krait venom, in order to identify such venom in the victim (38).

c. Russell's Viper: The venom causes local and hemotoxic manifestations with distinctive blister formation on the affected $\operatorname{limb}(41,48)$. It is used as a proteolytic agent alone or synergistically with others (29). Hematuria, renal failure, hyper edema, hemorrhage and anemia are other typical features in Russell's viper envenomation. This snake has a fatal dose of $15 \mathrm{mg}$ and the average venom yield per bite is $63 \mathrm{mg}(16)$. The purified protein of $15.3 \mathrm{kDa}$ molecular weight, with $L_{50}$ of $0.1 \mathrm{mg} / \mathrm{kg}$, is the most toxic PLA 2 reported from the Indian subcontinent (6).

d. Saw-Scaled Viper: It constitutes about $80 \%$ of the total venomous bites in some geographical areas (7). Ecchymosis, rise in CT/BT, hematological complications, local pain and edema can help in identifying an Echis bite (22). Untreated Echis envenomation may involve multiple organs and the patient may suffer from hematuria, melena, renal failure, hemorrhage, anemia and 
hypotension. No cases of any significant cardiotoxins have been reported by any research group but some case reports have indicated myocardial ischemia following viper bites $(4,25,35)$. The $L D_{50}$ is $6.65 \mathrm{mg} / \mathrm{kg}$ and an average bite may yield about $40 \mathrm{mg}$ of venom $(18,39)$. However, in the northern part of the subcontinent, because of the larger size of the endemic species, the average dose may be greater than the reported one.

e. Bamboo Pit Viper: It has a fatal dose of $100 \mathrm{mg}$ but the maximum extractable venom dose is only about $14 \mathrm{mg}(18)$. The bites are never alarmingly toxic and no mortality has been reported. However, PLA $2,14 \mathrm{kDa}$, is one of its main constituents, with a number of isoforms, and shows moderate anti-platelet activities, edema, mild anti-coagulating and myotoxicity resulting in local swelling, dizziness and morbidity (43).

f. King Cobra: Although king cobra envenomation cases are almost non-existent in the Indian subcontinent; its venom is functionally much similar to that of cobras, with limited variations like serine proteinase blood coagulation factor $X$ activator (27). A unique protein toxin ( $\mathrm{CM}_{55}-\mathrm{LD}_{50} 28 \mathrm{mg} / 20 \mathrm{~g}$ in albino mice) found in the venom has cardiotoxic and hemorrhagic characteristics, whereas the crude venom has a reported fatal dose of $12 \mathrm{mg}(15,18)$. However, it may contain and deliver venom many times the fatal dose because of its large venom glands.

g. Common Sea Snake: Its venom possesses potent post-synaptic neurotoxic activity with a fatal dose of $0.6 \mathrm{mg}$ for a $60-\mathrm{kg}$ body $(9,18)$. It is reported that nearly $80 \%$ of sea snake bites fail to produce significant envenomation, and bites may be inconspicuous, painless, and free of edema, but severe envenomation may cause neurological complications, oliguria, and hyperkalemic cardiac arrest (12).

\section{Opistoglyphs}

The grooved teeth may deliver Duvernoy's secretions, which are homologous to the venom gland secretions in Elapids and Viperids but functionally much milder. Hence, symptomatic manifestations are possible but may not be fatal. The posterior fang marks may be absent in the bite, but erythema, purpura or edema may develop locally. PLA $\mathrm{A}_{2}$ is widely spread in Colubridae venom (13). The venom may be mildly 
hemotoxic and thus the victim may feel dizziness for a couple of days with low-grade fever and local edema or erythema at the bite site. Sometimes, an accidental bite may look like an abrasion or a mechanical injury without significant symptoms. Nevertheless, the bite is either non-venomous or trivially venomous. However, Colubridae venom remains unexplored to a great extent and there is a rich opportunity for research in this area (23).

\section{Aglyphs}

These snakes do not have venom gland, fangs or any other venom delivery instrument, so they are non-venomous, but some of the frequent encounters may cause mechanical injury to human beings because of their maxillary teeth, and a tight grip by a python around the chest may lead to restricted respiration and asphyxia.

\section{SUMMARY OF MANIFESTATIONS}

To reduce the chances of a misdiagnosis and for a proper species classification, concise information is provided in Table 1 . Envenomation has also been graded according to the manifested symptoms. A grade may include the symptoms of its lower grades as well. Also, the Russell's viper bites may produce symptoms similar to those observed in saw-scaled viper because of the similarities observed in their hemotoxicity. 
Table 1: Symptomatic species-specific severity identification of venomous snakes from the Indian subcontinent.

\begin{tabular}{|c|c|c|c|c|c|}
\hline Species & $\begin{array}{l}\text { Grade I } \\
\text { Mild }\end{array}$ & $\begin{array}{l}\text { Grade II } \\
\text { Moderate }\end{array}$ & $\begin{array}{l}\text { Grade III } \\
\text { Severe }\end{array}$ & $\begin{array}{l}\text { Grade IV } \\
\text { Very Severe }\end{array}$ & $\begin{array}{l}\text { Distinct } \\
\text { Feature }\end{array}$ \\
\hline Viper & $\begin{array}{l}\text { One or two } \\
\text { punctures, } \\
\text { ecchymosis, } \\
\text { swelling, } \\
\text { local pain }\end{array}$ & $\begin{array}{l}\text { Rise in CT/BT, } \\
\text { edema, local } \\
\text { cyanosis, } \\
\text { bleeding from the } \\
\text { bite site }\end{array}$ & $\begin{array}{l}\text { Hemorrhage, } \\
\text { hematuria, } \\
\text { melena, } \\
\text { anemia, } \\
\text { coagulopathy }\end{array}$ & $\begin{array}{l}\text { Renal failure, } \\
\text { hypotension, } \\
\text { severe anemia, } \\
\text { reduction in } \\
\text { SpO2 }\end{array}$ & $\begin{array}{l}\text { Rapid } \\
\text { discoloratio } \\
\mathrm{n} \text { near the } \\
\text { puncture, } \\
\text { frequent } \\
\text { bites on the } \\
\text { apex }\end{array}$ \\
\hline Viper & $\begin{array}{l}\text { One or two } \\
\text { punctures, } \\
\text { ecchymose, } \\
\text { swelling, } \\
\text { local pain }\end{array}$ & $\begin{array}{l}\text { Along with the } \\
\text { above- } \\
\text { mentioned, } \\
\text { blisters on the } \\
\text { limb }\end{array}$ & $\begin{array}{l}\text { Along with the } \\
\text { above- } \\
\text { mentioned, } \\
\text { hyper edema, } \\
\text { blisters and } \\
\text { necrosis on } \\
\text { the limb }\end{array}$ & $\begin{array}{l}\text { Along with the } \\
\text { above- } \\
\text { mentioned, } \\
\text { hyper edema } \\
\text { and blisters on } \\
\text { the limbs }\end{array}$ & $\begin{array}{l}\text { Blisters } \\
\text { formation, } \\
\text { punctures } \\
\text { bigger and } \\
\text { wider than } \\
\text { those of } \\
\text { Saw-Scaled } \\
\text { Viper }\end{array}$ \\
\hline & $\begin{array}{l}\text { One or two } \\
\text { distinct fang } \\
\text { marks, local } \\
\text { pain, } \\
\text { ecchymosis } \\
\text { and swelling }\end{array}$ & $\begin{array}{l}\text { Sluggish optical } \\
\text { response, } \\
\text { edema, diplopia } \\
\text { and confusion }\end{array}$ & $\begin{array}{l}\text { Ptosis, dilated } \\
\text { pupils, local } \\
\text { necrosis, } \\
\text { arrhythmia, } \\
\text { respiratory } \\
\text { difficulty, low } \\
\text { SpO2, CNS } \\
\text { and cardiac } \\
\text { features }\end{array}$ & $\begin{array}{l}\text { hypotension, } \\
\text { unconscious } \\
\text { state, cardiac } \\
\text { arrest, } \\
\text { respiratory } \\
\text { arrest }\end{array}$ & $\begin{array}{l}\text { Rapid } \\
\text { cardiac and } \\
\text { systemic } \\
\text { features } \\
\text { with } \\
\text { prominent } \\
\text { local } \\
\text { features }\end{array}$ \\
\hline & $\begin{array}{l}\text { Miniscule } \\
\text { fang marks, } \\
\text { difficulty in } \\
\text { swallowing } \\
\text { after 5-12 } \\
\text { hours }\end{array}$ & $\begin{array}{l}\text { Sluggish optical } \\
\text { response, ptosis, } \\
\text { diplopia, } \\
\text { glossopharyngeal } \\
\text { dysfunction, } \\
\text { hypokalemia. }\end{array}$ & $\begin{array}{l}\text { Dilated pupils, } \\
\text { ptosis, low } \\
\text { SpO2, poor } \\
\text { respiration, } \\
\text { arrhythmia, } \\
\text { glossopharyng } \\
\text { eal palsy, colic }\end{array}$ & $\begin{array}{l}\text { Hypotension, } \\
\text { unconscious } \\
\text { state, coma, } \\
\text { respiratory } \\
\text { arrest, sudden } \\
\text { cardiac arrest }\end{array}$ & $\begin{array}{l}\text { Minimal } \\
\text { local } \\
\text { symptoms, } \\
\text { colic and } \\
\text { hypokalemi } \\
\text { a }\end{array}$ \\
\hline
\end{tabular}




\section{SCORPION ENVENOMATION}

Snake and scorpion habitats are not much different. Areas of vast vegetation and damp and moderately warm climate are their common choicest domicile. Scorpion envenomation in children can be a potentially fatal condition. Neurotoxins and cardiotoxins are present in the majority of scorpion venoms (28), which affects the cardiovascular system, the central nervous system and causes pulmonary edema along with severe local pain (49). Thus, it is highly probable that a person stung by a scorpion may be taken as a case of Elapid (cobra or krait) snakebite and may be treated with anti-snake venom serum, leading to some unsolicited complications.

The simplest distinguishing features between the neurotoxicity of an Elapid envenomation and a scorpion envenomation are peripheral hypothermia, variations in serum blood glucose and pupil reaction to light (34).

\section{CONCLUSION}

As per the recommendations of WHO, the most effective treatment for snakebite is the administration of monospecific ASV (45). Hence, the identification of the aggressor species becomes the utmost requirement for medical management. Attempts have been made to develop field ELISA kits and electronic immunosensors for identification of the species $(38,39)$. Until the definitive methods become commercially available and viable, the attending medical staffs have to depend on their wisdom and capability to classify the species and assess the envenomation severity.

In this paper, an attempt was made to explain the toxicity of individual species and species-specific symptoms developed in the victims of snakebites, which may help in the proper identification of the aggressor and in grading the envenomation. However, due to a number of reasons, management of snakebite cases in the Indian subcontinent is a challenge and needs a networked and well-coordinated effort across the boundaries of the nations.

\section{ACKNOWLEDGEMENTS}

The authors wish to acknowledge Dr. Vinod Kumar Mahobia, Ex-Professor, Govt. P. G. College Kota, India, for his invaluable help and knowledge imparted in understanding different snakes and their medical importance. The generosity of Dr. 
Chris Thompson, Royal Prince Alfred Hospital, Sydney; Dr. P. Gopalakrishnakone, Venom and Toxin Research Programme, National University of Singapore; Dr. Girish Mathur, Senior Physician, Kota; Dr. K. C. Nayak, S. P. Medical College, Bikaner; and Mr. Aaron Lobo, researcher on sea snakes of the Gulf of Mannar, India, are gratefully acknowledged for providing invaluable support. Prof. B. M. J. Pereira and Dr. V. Pruthi, Department of Biotechnology, Indian Institute of Technology, Roorkee, are acknowledged for their help in understanding different immunological concepts. Finally, the authors wish to acknowledge Indian Institute of Technology, Roorkee, and Engineering College, Kota, for their consistent patronage.

\section{REFERENCES}

1 AGRAWAL PN., AGgARWAL AN., GUPTA D., BEHERA D., PRABHAKAR S., JINDAL SK. Management of respiratory failure in severe neuroparalytic snake envenomation. Neurol. India, 2001, 49, 25-8.

2 BAWASKAR HS. Snake venoms and antivenoms: critical supply issues. J. Assoc. Physicians India, 2004, 52, 11-3.

3 BHARAT SERUM, VACCINES LTD. THANE Snake Venom Antiserum I.P., 2001.

4 BLONDHEIM DS., PLICH M., BERMAN M., KHAIR G., TZVIG L., EZRI J, MARMOR AT. Acute myocardial infarction complicating viper bite. Am. J. Cardiol., 1996, 78, 492-3.

5 BOMB BS., ROY S., KUMAWAT DC., BHARJATYA M. Do we need anti-snake venom (ASV) for management of elapid ophitoxaemia? J. Assoc. Physicians India, 1996, 44, 31-3.

6 CHAKRABORTY AK., HALL RH., GHOSE AC. Purification and characterization of a potent hemolytic toxin with phospholipase $A 2$ activity from the venom of Indian Russell's viper. Mol. Cell. Biochem., 2002, 237, 95-102.

7 CHAND R., NAYAK KC., GUPTA RP., CHADDA S., CHADDA VS. A study of polyvalent antivenom serum therapy in delayed cases of viper snake bite. Ind. Med. Gaz., 1990, 124, 256-60.

8 CHER CDN., ARMUGAM A., ZHU YZ., JEYASEELAN K. Molecular basis of cardiotoxicity upon cobra envenomation. Cell. Mol. Life Sci., 2005, 62, 105-18. 
9 CHETTY N., DU A., HODGSON WC., WINKEL K., FRY BG. The in vitro neuromuscular activity of Indo-Pacific sea-snake venoms: efficacy of two commercially available antivenoms. Toxicon, 2004, 44, 193-200.

10 COSTA LA., FORNARI MC., BERARDI VE., MILES HA., DIEZ RA. In vivo effect of snake phospholipase A2 (crotoxin + cardiotoxin) on serum IL-1 alpha, TNFalpha and IL-1ra level in humans. Immunol. Lett., 2001, 75, 137-41.

11 CREER S., MALHOTRA A., THORPE RS., STOCKLIN R., FAVREAU PS., HAO $\mathrm{CHOU}$ WS. Genetic and ecological correlates of intraspecific variation in pitviper venom composition detected using matrix-assisted laser desorption time-of-flight mass spectrometry (MALDI-TOF-MS) and isoelectric focusing. J. Mol. Evol., 2003, 56, 317-29.

12 FOSTER J. Snake envenomations, sea. eMedicine, [serial online], 2005, 1-11 [cited 2005 May 04]. Available from: http://www.emedicine.com/emerg/topic543.htm.

13 FRY BG., WUSTER W., RYAN RAMJAN SF., JACKSON T., MARTELLI P., KINI RM. Analysis of Colubroidea snake venoms by liquid chromatography with mass spectrometry: evolutionary and toxinological implications. Rapid Commun. Mass Spectrom., 2003, 17, 2047-62.

14 GAN GL. Snake venoms. The Singapore Family Physisian, 2002, 28, 40-54.

15 GOMES A., DE P., DASGUPTA S.C. Occurrence of a unique protein toxin from the Indian King Cobra (Ophiophagus hannah) venom. Toxicon, 2001, 39, 36370.

16 HAZRA A. Poisonous snake bites in India. Community Dev. Med. Unit Ration. Drug. Bull., 2003, 30, 1-12.

17 HUANG SJ., KWAN CY. Inhibition by multivalent cations of contraction induced by Chinese cobra venom cardiotoxin in guinea pig papillary muscle. Life Sci., 1996, 59, 55-60.

18 JENA I., SARANGI A. Snakebite. In: JENA I., SARANGI A. Snakes of medical importance and snake-bite management. New Delhi: Ashish Publishing House, 1993: 99-105.

19 KULARATNE SAM. Common krait (Bungarus caeruleus) bite in Anuradhapura, Sri Lanka: a prospective clinical study, 1996-1998. Postgrad. Med. J., 2002, $78,276-80$. 
20 KUMAR SR. Snake bite: an experience. J. Bombay Nat. Hist. Soc., 1991, 88, 460.

21 KUMAR TKS., PANDIAN STK., JAYARAMAN G., PENG HJ., YU C. Understanding the structure, function and folding of cobra toxins. Proc. Natl. Sci. Counc. Repub. China B, 1999, 23, 1-19.

22 LAKHOTIA M., KOTHARI D., CHOUDHARY DR., SHARMA S., JAIN P. A case of saw scale viper snakebite presenting as pleuro-pericardial haemorrhage. $J$. Indian Acad. Clin. Med., 2002, 3, 392-4.

23 LUMSDEN NG., FRY BG., KINI RM., HODGSON WC. In vitro neuromuscular activity of 'colubrid' venoms: clinical and evolutionary implications. Toxicon, 2004, 43, 819-27.

24 MAGUIRE JH., SPIELMAN A. Ectoparasite infestations and arthropod bites and stings. In: FAUCI AS., BRAUNWALD E., ISSELBACHER KJ., WILSON JD., MARTIN JB., KASPER DL., HAUSER SL., LONGO DL., HARRISON TR. EdS. Harrison's principles of internal medicine. 14.ed. Boston: McGraw-Hill. 1998: 2548-54.

25 MAHESHWARI M., MITTAL SR. Acute myocardial infarction complicating snakebite. J. Assoc. Physicians India, 2004, 52, 63-4.

26 MALHOTRA A., THORPE RS. A phylogeny of the Trimeresurus group of pit vipers: new evidence from a mitochondrial gene tree. Mol. Phylogenet. Evol., 2000, 16, 199-211.

27 MARKLAND FS. Snake venoms and the hemostatic system. Toxicon, 1998, 36, 1749-1800.

28 MEKI AR., EL-DEEN ZM., EL-DEEN HM. Myocardial injury in scorpion envenomed children: significance of assessment of serum troponin I and interleukin-8. Neuroendocrinol. Lett., 2002, 23, 133-40.

29 NAKAMURA M., TANAKA M., ABE S., FUJIWARA H. Sudden pressure elevation can trigger acute muscle cell death of the heart and aorta. Atherosclerosis, 1999, 146, 25-32.

30 NAYAK KC., JAIN AK., SHARDA DP., MISHRA SN. Profile of cardiac complications of snake bite. Indian Heart J., 1990, 42, 185-8.

31 NAYAK KC., SHARDA DP., KOCHAR D., VARMA VK. Epidemiological study of snake bites in Western Rajasthan in the years 1981-1985. Ind. Med. Gaz., 1988, 122, 121-6. 
32 NIRTHANAN S., GOPALAKRISHNAKONE P., GWEE MC., KHOO HE., KINI RM. Non-conventional toxins from elapid venoms. Toxicon, 2003, 41, 397-407.

33 NORRIS RL., OSLUND S., AUERBACH PS. Disorders caused by reptile bites and marine animal envenomations. In: FAUCI AS., BRAUNWALD E., ISSELBACHER KJ., WILSON JD., MARTIN JB., KASPER DL., HAUSER SL., LONGO DL., HARRISON TR. Eds. Harrison's principles of internal medicine. 14.ed. Boston: McGraw-Hill, 1998: 2544-8.

34 RADHA KRISHNA MURTHY K., ABBAS ZARE M. Scorpion antivenom reverses metabolic, electrocardiographic and hormonal disturbances caused by the Indian red scorpion Mesobuthus tamulus concanesis, pocock envenomations. J. Venom. Anim. Toxins, 2002, 8, 30-48.

35 SAADEH AM. Case report: acute myocardial infarction complicating a viper bite. Am. J. Trop. Med. Hyg., 2001, 64, 280-2.

36 SAINI RK., SINGH S., SHARMA S., GUPTA VK. Effects of single dose versus serial administration of antivenom serum on coagulation defects in snake bite. Indian J. Pharmacol., 1984, 16, 170-1.

37 SAXENA SC., KUMAR V., MAHESHWARI R., SHARMA A. Development of a computerized QECG acquisition and classification system. In: INTERNATIONAL CONFERENCE ON BIOMEDICAL ENGINEERING, Chennai, 2001. Proceedings... Chennai: Anna University, 2001. p.115-9.

38 SELVANAYAGAM ZE., GNANAVENDHAN SG., GANESH KA., RAJAGOPAL D., RAO PV. ELISA for the detection of venoms from four medically important snakes of India. Toxicon, 1999, 37, 757-70.

39 SELVANAYAGAM ZE., NEUZIL P., GOPALAKRISHNAKONE P., SRIDHAR U., SINGH M., HO LC. An ISFET-based immunosensor for the detection of betabungarotoxin. Biosens. Bioelectron., 2002, 17, 821-6.

40 SENEVIRATNE U., DISSANAYAKE S. Neurological manifestations of snake bite in Sri Lanka. J. Postgrad. Med., 2002, 48, 275-9.

41 SHARMA N., CHAUHAN S., FARUQI S., BHAT P., VARMA S. Snake envenomation in a North Indian hospital. Emerg. Med. J., 2005, 22, 118-20.

42 SIVARAMAN T., KUMAR TK., TU YT., PENG HJ., YU C. Structurally homologous toxins isolated from the Taiwan cobra (Naja naja atra) differ significantly in their structural stability. Arch. Biochem. Biophys., 1999, 363, 107- 15. 
43 TSAI IH., WANG YM., CHEN YH., TSAI TS., TU MC. Venom phospholipases A2 of bamboo viper (Trimeresurus stejnegeri): molecular characterization, geographic variations and evidence of multiple ancestries. Biochem. J., 2004, 377, 215-23.

44 WHITAKER R. Common Indian snakes: a field guide. New Delhi: Macmillan, 1978. 154p.

45 WORLD HEALTH ORGANIZATION. Regional Office for South-East Asia. Management of snake bites in South East Asia. The Clinical Management of Snake Bites in the Southeast Region Asia [serial online], 2003, [cited 2005 May 04]. Available from: http://w3.whosea.org/bct/snake/5.htm.

46 WU CY., CHEN WC., HO CL., CHEN ST., WANG KT. The role of the N-terminal leucine residue in snake venom cardiotoxin II (Naja naja atra). Biochem. Biophys. Res. Commun., 1997, 233, 713-6.

47 WU W. Cobra cardiotoxin and phospholipase A2 as GAG-binding toxins: on the path from structure to cardiotoxicity and inflammation. Trends Cardiovasc. Med., 1998, 8, 270-8.

48 YAMADA D., SEIKIYA F., MORITA T. Prothrombin and factor $X$ activator activities in the venoms of viperidae snakes. Toxicon, 1997, 35, 1581-9.

49 YUGANDHAR B., MURTHY KRK, SATTAR SA. Insulin administration in severe scorpion envenoming. J. Venom. Anim. Toxins, 1999, 5, 200-19.

50 ZHANG Y., TU AT. The effect of snake venom and their components on adrenomedullary cells: catecholamine efflux and cell damage. Neurotoxicology, 2002, 23, 273-9. 